Türk Coğrafya Dergisi
Sayı 62: 9-19, Istanbul
http://www.tcd.org.tr

Hakemli Makale

Reviwed Article

\title{
Aladağlarda (Orta Toroslar) kaynak konumlu bir mağara: Derebağ mağarası (Yahyalı-Kayseri)
}

\author{
A spring-type cave in the Aladağ Mountains (Central Taurus): Derebă̆ cave (Yahyalı- \\ Kayseri)
}

Ibrahim KOPAR ${ }^{a}$ Emin TOROĞLU

a) Atatürk Üniversitesi, Edebiyat Fakültesi, Coğrafya Bölümü.

b) Kahramanmaraş Sütçü İmam Üniversitesi, Fen-Edebiyat Fakültesi, Coğrafya Bölümü.

Geliș/Received: 17.11.2013 Kabul /Accepted: 30.01.2014

Sorumlu yazar/Corresponding author (i. KOPAR) ikopar@atauni.edu.tr
Öz

Orta Toroslarda yer alan Aladağlar $(3756 \mathrm{~m}$ ) çeşitli tip ve boyutlara sahip karstik mağaralar bakımından oldukça zengindir. Derebağ Mağarası da bunlardan biridir. Mağara, Aladağların kuzeydoğusundaki Yahyalı (Kayseri) ilçesine bağlı Derebağ Kasabası'nın Çağlayan (Elmabağı) Mahallesi sınırları içinde yer almaktadır. Sahadaki yeraltı suyu sisteminin bir unsurunu oluşturan mağara, Siyah Aladağ Birliği'ne ait Üst Permiyen kireçtaşları içerisinde ana hatlarıyla kuzeybatı-güneydoğu ve kuzey-güney doğrultulu çatlaklar boyunca gelişmiştir. Mağara "T" şekilli olup, biri ana galeri diğeri bir dirsekle ona bağlanan elipsoidal şekilli geçit galerisi olmak üzere iki bölümden oluşmaktadır. Ana galeriden gelen sular mağaranın farklı genişlikteki ağızlarından çıkmakta ve 16 metrelik bir diklikten düşerek Derebağ Şelalesi'ni oluşturmaktadır. Derebağ Mağarası'nın girişi deniz düzeyinden 1463 metre, vadi tabanından ise 63 metre yukarıda yer almaktadır. Mağaranın toplam uzunluğu 90 metredir. Hidrolojik bakımdan mağara, sifon görevini üstlenen geçit galerisinde zaman zaman su bulundurması yönüyle yarı aktif, ana galeri ve alt geçitlerde sürekli su bulundurmasıyla aktif durumdadır. Ana galeriden gelen suyun mağara ağzından dışarıya çıkması nedeniyle de kaynak konumludur. Damlataşı şekilleri bakımından fakir olmasına rağmen mağaranın sahip olduğu diğer özellikler mağarayı ilginç hale getirmektedir. Mağaranın şelaleyle birlikte eko-turizme kazandırııması doğal yapının korunmasına olduğu kadar yöre insanına da ekonomik açıdan olumlu katkılar sağlayacaktır.

Anahtar Kelimeler: Aladağlar, Derebağ Mağarası, Yahyalı, Kayseri, Türkiye.

\section{ABSTRACT}

The Aladağ Mountains (3756 meter) in Central Taurus mountain range are very rich in karstic cave formations of various types and dimensions. One of such caves is Derebağ Cave. The mentioned cave is located in the Çağlayan (Elmabağı) Quarter of Derebağ Town, Yahyal,, Kayseri. One of the elements of the underground water system in the related area, the cave has been formed within the unit made up of Upper Permian limestone, which are one of the limestones of the Black Aladağ Mountains, and through the cracks that lie with the main lines northwest-southwest and north-south. Having a Tshape, the cave is divided into two parts, one of them being the main gallery and the other one being the ellipsoidal passage gallery that is connected to the main gallery through an elbow. The waters coming from the main gallery come out from the mouths of the cave, which are of various widths, and form Derebağ waterfall falling down from a 16 meter-escarpment. The entrance of the Derebağ Cave is 1463 meter above the sea level and 63 meter above the valley bottom. Total length of the cave is 90 meters. Hydrologically, the cave is semi-active in that it from time to time reserves water in the passage gallery, which is like a syphon, and is active in that it always reserves water in the main gallery and lower passages. The cave is spring-type in that the water from the main gallery comes out from the mouth of the cave. Although poor in dripstone shapes, the cave is interesting with its other characteristics. If this cave is opened to eco-tourism together with the fall, it will not only help the protection of the natural formation but positively affect the local people's economy. Keywords: Aladağ Mountains, Derebağ Cave, Yahyalı, Kayseri, Türkiye. 


\section{Giriş}

Türkiye'de çözünebilen kayaçların (kireçtaşı, dolomit, jips vb.) geniş yer tutması doğal olarak hemen her türden karstik şeklin gelişmesini sağlamıştır. Bu şekillerden biri de yeraltı (derinlik) karstıyla oluşan mağaralardır. Mağaralara en fazla Akdeniz Bölgesi (Batı ve Orta Toroslar) başta olmak üzere Marmara Bölgesi'nin Güney Marmara Bölümü, Karadeniz Bölgesi'nin Batı ve Doğu Karadeniz bölümlerinde, Doğu Anadolu Bölgesi'nin kuzey ve güney kesimleri ile i̇ç Batı Anadolu'da rastlanmaktadır (Nazik, 1989; Sür: 1994). Bu sahalarda $35-40$ bin mağara bulunmakla birlikte bunların sadece 1250 kadarının Türkiye mağara envanterine girdiği (Nazik vd., 2005) ancak bunların önemli bir bölümünün ya isim ölçeğinde bilindiği ya da detaylı çalışılmadığı anlaşılmıştır.

Orta Torosların önemli bir kütlesi olan Aladağlar'da (Demirkazık tepe, 3756 m) çeşitli tip ve büyüklükte 300'den fazla mağara bulunmaktadır. Farklı yükselti kademelerinde bulunan bu mağaralardan 266 tanesinin giriş kotu 2000 metrenin üzerindedir (Törk, 2008). Diğerleri ise Zamantı Irmağı yerel taban seviyesi (650 m) ile 2000 metre arasında yer almaktadır. İşte bu mağaralardan biri de Aladağların kuzeydoğu uzantısında giriş kotu 1463 metrede bulunan Derebağ (Çağlayan) Mağarası'dır. Mağara, hidrolojik bakımdan birden fazla durumu bir arada göstermektedir. Nitekim ana galeri ve onunla bağlantılı alt geçitlerde sürekli su bulunması nedeniyle aktif, ağzı dışarıya açılan sifon özellikli geçit galerisinde ise yarı aktif duruma sahiptir. Ana galeriye bağlanan geçit galerisinin altındaki başka boşluklardan geçen suyun tekrar mağara ağzından çıkması nedeniyle de kaynak konumlu mağara özelliği göstermektedir. Mağaradan çıkan sular şelale oluşturmaktadır. Bu bakımdan hem mağara hem de mağara ağzından çıkan suyun oluşturduğu Derebağ Şelalesi iki önemli doğal zenginlik olarak aynı konumu paylaşmaktadır.

Bu makalede öncelikle Derebağ Mağarası́nın özelliklerine yer verilmiş şelaleye ise belli başlı özellikleriyle konu içinde değinilmiştir. Şelalenin çevresi günübirlik kullanıma dönük rekreasyon alanı şeklinde düzenlenmiştir. Mağarayla ilgili herhangi bir düzenleme yapılmamıştır. Bunda mağaranın doğal yapısının her ziyaretçinin girmesine kolay imkân vermemesi rol oynamaktadır. Nitekim Nazik, ilginç özellikleri olan mağaraya belirli teçhizatlar sağlandıktan sonra bir rehber eşliğinde girilmesini önermektedir (Nazik, 2008).

Mağaraların incelenerek Türkiye mağara envanterine kazandırılması, mağara zenginliğinin ortaya çıkarılması bakımından çok önemlidir. Ayrıca mağaralardan elde edilen bilgilerle sahanın tektonik ve jeomorfolojik gelişimi hakkındaki ipuçlarına ulaşılabilmektedir. Bu nedenle mağara araştırmalarına ağırlık verilmesi ve desteklenmesi gerekmektedir.

\section{AMAÇ ve YÖNTEM}

Bu çalışmada iki ana hedef belirlenmiştir. Birinci hedef; Derebağ Mağarası'nın yapısal ve görsel özelliklerini ortaya koyarak bundan sonra yapılacak aynı içerikte çalışmalara bilimsel bir temel oluşturmaktır. İkincisi ise; mağaranın ulusal ölçekte tanıtımını sağlayarak bölgenin turizm potansiyeline yeni bir değeri kazandırmaktır. Bu amaçlar doğrultusunda mağara sahasına değişik zamanlarda gidilerek mağara içinde ve yakın çevresinde etütler yapılmıştır. Mağaradaki uzunluk ölçümlerinde lazer metre, sıcaklık ve nem durumunun belirlenmesinde ise termohigrometre cihazlarından yararlanılmıştır. Ayrıca mağaranın özelliklerini daha iyi yansıtabilmek amacıyla çeşitli haritalar (lokasyon, topografya, jeoloji, jeomorfoloji), plan ve kesitler (jeolojik dikme kesit, izdüşürülmüş boyuna kesit) hazırlanmıştır.

\section{DEREBAĞ MAĞARASI'NIN YERI ve DOĞAL ORTAM ÖZELLIKLERI}

Mağara, Akdeniz Bölgesi'nin Adana Bölümü’ndeki Orta Toroslar'ın en yüksek kütlesi olan Aladağların (3756 m) kuzeydoğusundaki Yahyalı (Kayseri) ilçesine bağlı Derebağ Kasabası'nın Çağlayan Mahallesi sınırları içinde yer almaktadır. Mağaranın giriş yerinin koordinatları $38^{\circ} 03^{\prime}$ $06^{\prime \prime}$ kuzey ve $35^{\circ} 17^{\prime} 37^{\prime \prime}$ doğu'dur. Saha kuzeyden Sultansazlığı Havzası, güney-güneybatıdan Aladağlar'ın zirveleri ve Alagöl Dağı (3333 m), batıdan Ecemiş koridoru, doğudan ise Zamantı Irmağı vadisi tarafından sınırlandırılmıştır (Şekil 1).

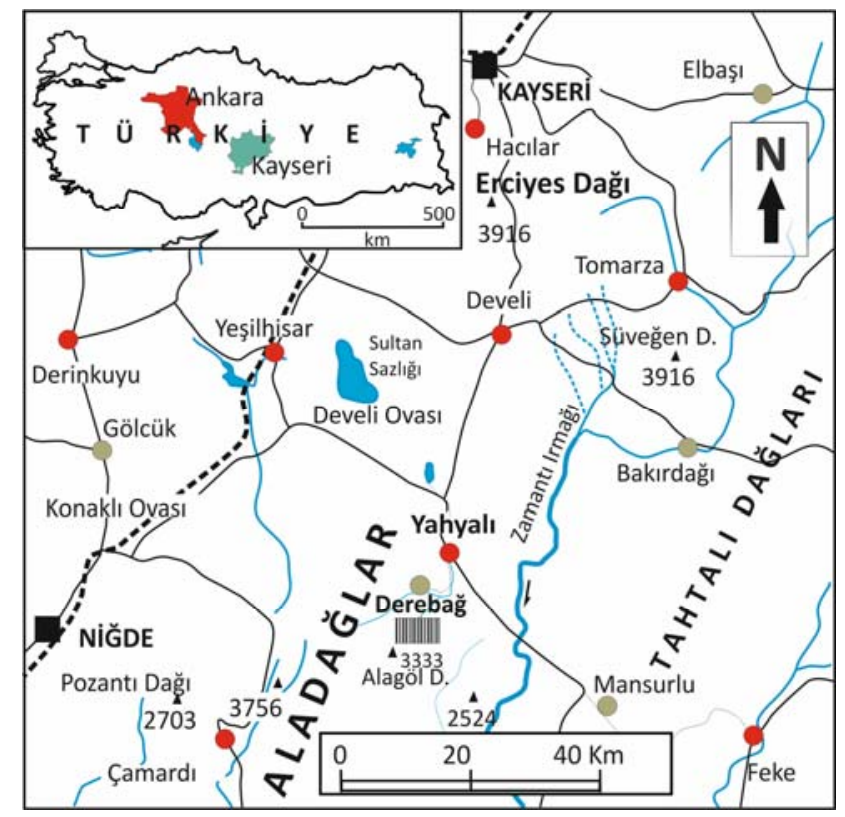

Şekil 1. Araştırma sahasının lokasyon haritası.

Figure 1. Location map of the study area.

Mağara sahası topoğrafik açıdan Aladağların önemli yükseltilerinden biri durumundaki Alagöl Dağı'nın (3333 m) kuzeydoğu uzantısında yer alan Ketir tepe (1746 m), Kale tepe $(2391 \mathrm{~m})$, Düzkuyu tepe (2489 m), Keklicek tepe (2443 m) ve Düden tepe (2324 m) gibi çok sayıda tepenin kuşattığı, Yahyalı Çayı ve kolları tarafından yer yer derince yarılmış arızalı bir rölyefe sahiptir (Şekil 2). 


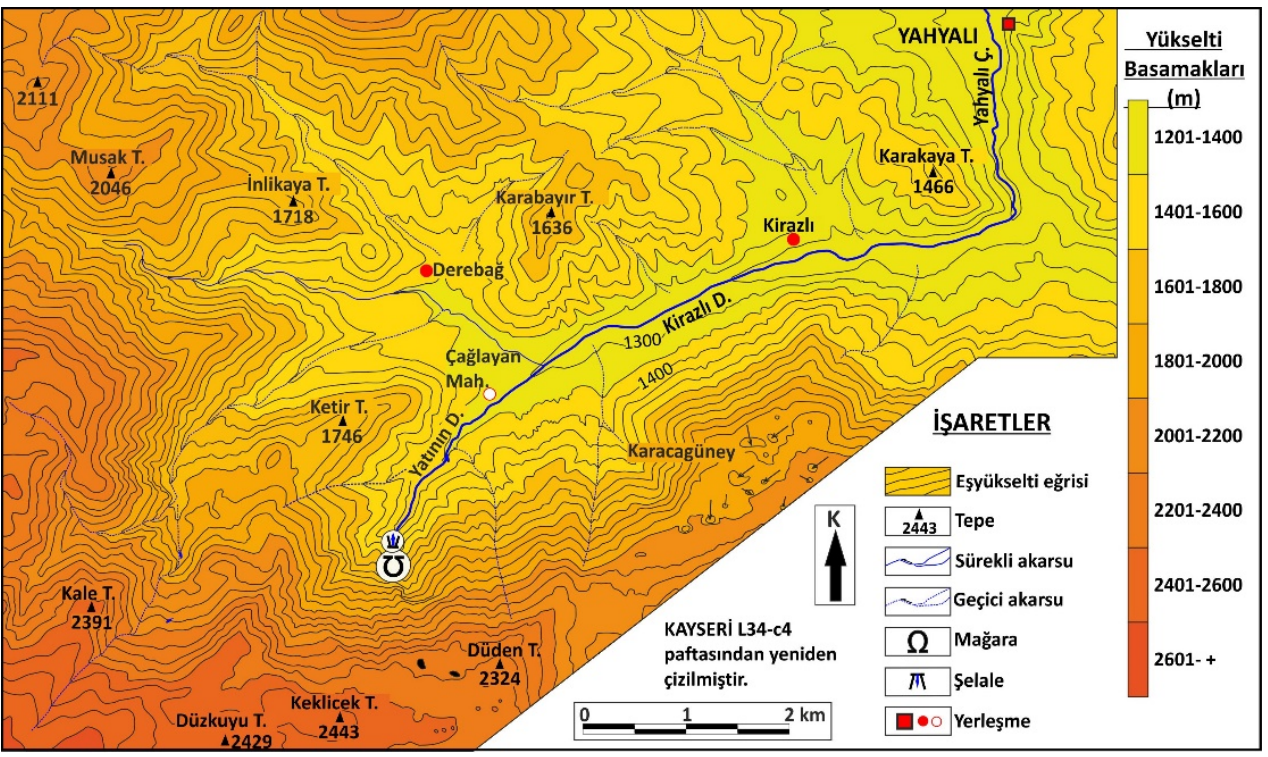

Şekil 2. Araştırma sahasının topografya haritası.

Figure 2. Topographical map of the study area.

Derebağ Mağarası'nın Yahyalı ilçe merkezine uzaklığı kuş uçuşu 8 kilometredir. Kirazlı dere vadisini takip ederek yörede iyi bilinen Derebağ Şelalesi'ne ulaşıldığında mağaraya da ulaşılmış olmaktadır. Ancak mağara ağzına ulaşmak için öncelikle mağara ağzından çıkan suyun düştüğü, demir bir çitle tek taraflı olarak çevrilmiş dikliği geçmek gerekmektedir. Ayrıca çit çevresinde zemindeki ıslanmış su yosunlarının oluşturduğu kaygan yüzey de mağara ağzına ulaşılmasını zorlaştıran önemli bir faktördür.

Litolojik Özellikler: Orta Toroslar naplaşmaya bağlı olarak çok sayıda tektonik birliğin yer aldığı karmaşık yapılı bir sahadır. Bu yapıda önemli bir konuma sahip olan Aladağlar kıta kenarı çökelleri ile ofiyolitlerden oluşmaktadır. Kıta kenarı çökelleri; Üst Paleozoyik ve Mesozoyik Siyah Aladağ kireçtaşları ile Mesozoyik Beyaz Aladağ kireçtaşları tarafından temsil edilmektedir (Blumenthal, 1941; Blumenthal, 1952; Özgül, 1976; Tekeli, 1980a). Ofiyolit dizisi ise Üst Triyas-Alt Kretase'de duraylı olan kıta kenarının Senoniyen'de bozulmasıyla sahaya yerleşmiştir. $\mathrm{Bu}$ birimler Maestrihtiyen'deki sıkıştırma hareketleriyle naplaşmaya maruz kalarak tektonik yüzeyler boyunca taşınarak günümüzdeki konumlarını kazanmıştır. Otokton birimler üzerinde yer alan naplı birimler, kuzeyden güneye doğru Yahyalı, Siyah Aladağ, Üst Kuşak, Çataloturan ve Beyaz Aladağ naplarıdır (Tekeli, 1980a; Tekeli, 1980b). Derebağ Mağarası ve yakın çevresinde Çataloturan, Siyah Aladağ ve Yahyalı naplarına ait istifler yer almaktadır (Şekil 3). Çataloturan istifi Karbonifer ince tabakalı kireçtaşlarıyla temsil edilmektedir. Siyah Aladağ birliğinde kalın tabakalı Karbonifer kireçtaşı ve kuvarsit ara katkılı kireçtaşları ile Alt Permiyen Girvenellalı kireçtaşı ve Üst Permiyen Mizzialı (Alg) kireçtaşları yüzeylenmektedir. Yahyalı istifinde ise alt şist (Silüriyen (?)-Devoniyen), üst şist (Karbonifer) serisine ait kayaçlar ile kalkşist (Devoniyen) ve kristalize kireçtaşları (Devoniyen) yer almaktadır (Ayhan vd., 1984).

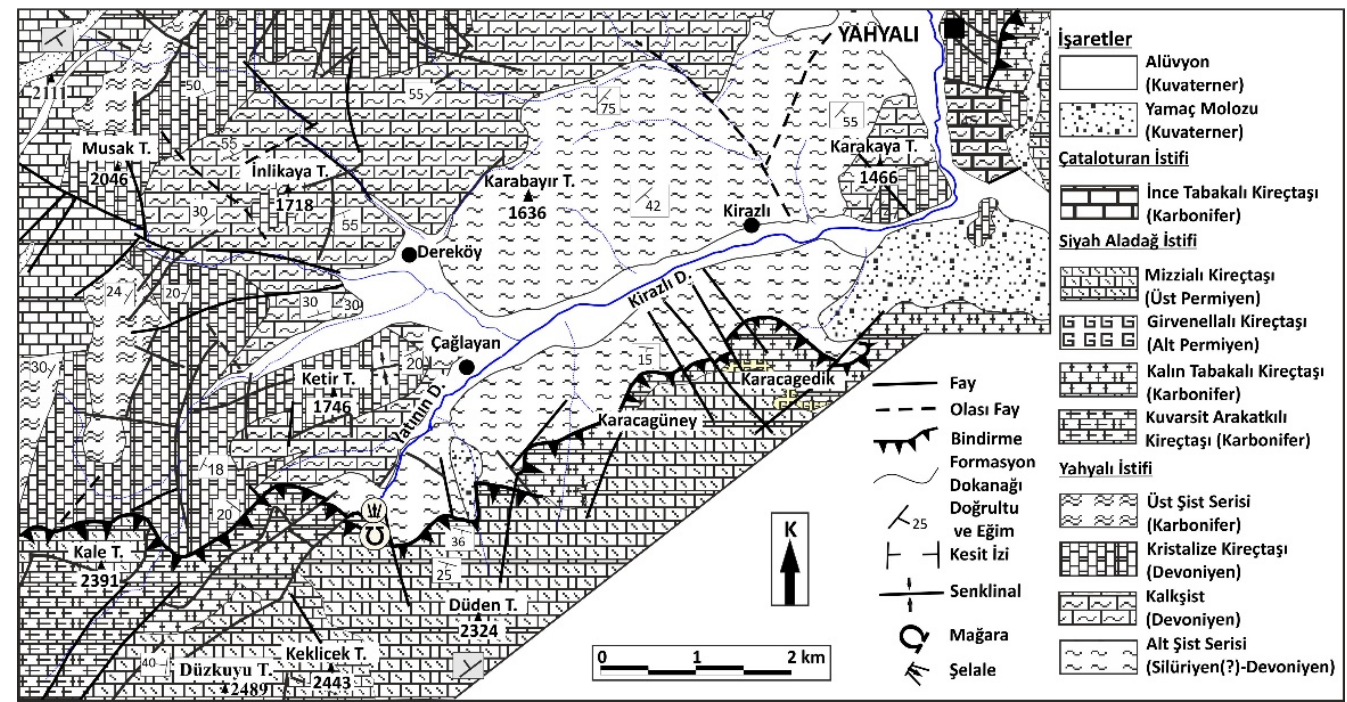

Şekil 3. Araştırma sahasının jeoloji haritası (Ayhan vd., 1984).

Figure 3. Geological map of the study area (from Aayhan et al., 1984). 
Derebağ Mağarası Siyah Aladağ birliğinde geniş alan kaplayan Üst Permiyen Mizzialı kireçtaşları içinde gelişmiştir. Çelik (1997) tarafından Zindandere formasyonu olarak yeniden isimlendirilen birim yaklaşık olarak 925 metre kalınlıktadır (Çelik, 1997). Bol miktarda fosil (Mizzia Sp., Agathamina Sp., Geinitzina Sp., Globivalvulina Sp., Glomospira Sp., gibi) içermektedir (Ayhan vd., 1984). Kireçtaşını oluşturan tabakaların kalınlığı ise 30-70 santimetre arasında değişmektedir (Çelik, 1997). Düzenli tabakalanma gösteren kireçtaşları gri-koyu ile gri-siyah arasında renklere sahip olup oldukça çatlaklı yapıdadır (Fotoğraf 1a). Diyajenezle bağlantılı gelişmiş çatlaklarda yer yer demir bileşiklerinden (?) oluşan dolgular (Fotoğraf 1b) İzlenmektedir (Ayhan vd., 1984). Bu çatlakların dolaşım sistemindeki yer altı suyu tarafından zamanla aşındırılması Derebağ Mağarası'nı meydana getiren boşlukların oluşum ve gelişimine olanak vermiştir. Buna göre her boşluk anakayayı etkileyen bir çatlak sistemini temsil etmektedir.

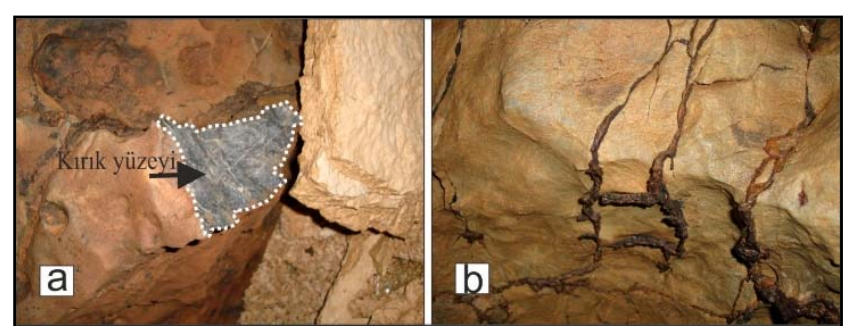

Fotoğraf 1. (a) Gri-koyu ile gri-siyah renkli mizzialı kireçtaşı. Mağara içinden alınan fotoğrafta kesik çizgilerle belirtilen taze kırık yüzeyinde kayacın rengi daha net görünmektedir. (b) Kireçtaşı bol çatlaklı olup yer yer demir bileşikleriyle (?) dolguludur (Ayhan vd., 1984).

Photograph 1. (a) The black-grey and grey-black limestone with a mizzia on. The colour of the rock is clearer on the new cracked surface, which is indicated by dashed lines in the photograph taken from inside the cave. (b) The limestone has many cracks and is iron compounds (?)-filled in patches (Ayhan et al., 1984: 28).
Çalışma sahasındaki naplı yapı ve farklı doğrultulara (KDGB; KB-GD vb.) sahip fay sistemleri en dikkat çeken tektonik yapılardır. Naplaşma ve faylar farklı jeolojik dönemleri temsil eden yoğun tektonik olaylar sonucunda oluşmuştur (Ayhan vd., 1984). Bu yüzden sahadaki formasyonların tektonik dokanaklı olduğu görülmektedir. Nitekim mağaranın oluştuğu kireçtaşları batıya doğru kalın tabakalı Karbonifer kireçtaşları ve kuvarsit ara katkılı kireçtaşlarıyla dokanaklıdır (Şekil 4). Sahadaki diğer litolojik birimler Kuvaterner yamaç molozları ve alüvyonlardan meydana gelmektedir. Çevredeki farklı kayaçlardan sağlanan malzeme taşıyıcı etmenin (akarsu, sellenme) gücüne göre yamaçlarda ve vadi tabanlarında biriktirilmiştir.

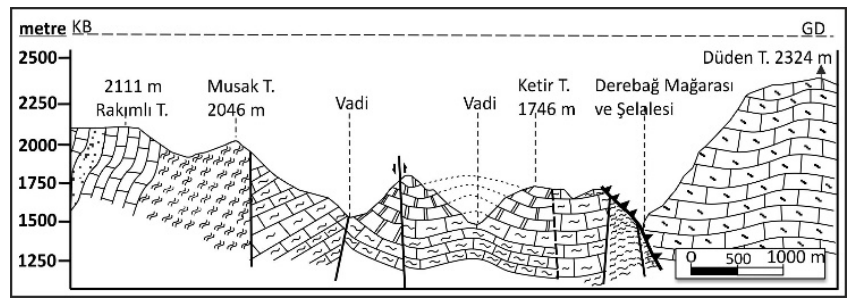

Şekil 4. Derebağ Mağarası ve çevresinin jeolojik kesiti (Ayhan vd., 1984 den yararlanılarak).

Figure 4. Geological cross section of the Derebağ cave and surrounding places (benefiting from Ayhan et al., 1984).

Jeomorfolojik Özellikler: Alpin orojenik silsilesinin güney kanadında yer alan Aladağlar, Alpin ve Post Alpin tektonik hareketlerden etkilenerek bölgesel ölçekte blok yükselme, kıvrılma, kırılma ve bindirmelere maruz kalmıştır (Kopar 2009). Bu yüzden kütle tektonik hareketlerle oluşan şekillerle glasiyal, karstik ve flüviyal etmen ve süreçler tarafından oluşturulmuş şekillerin bir arada olduğu oldukça arızalı bir rölyefe sahip olmuştur (Şekil 5).

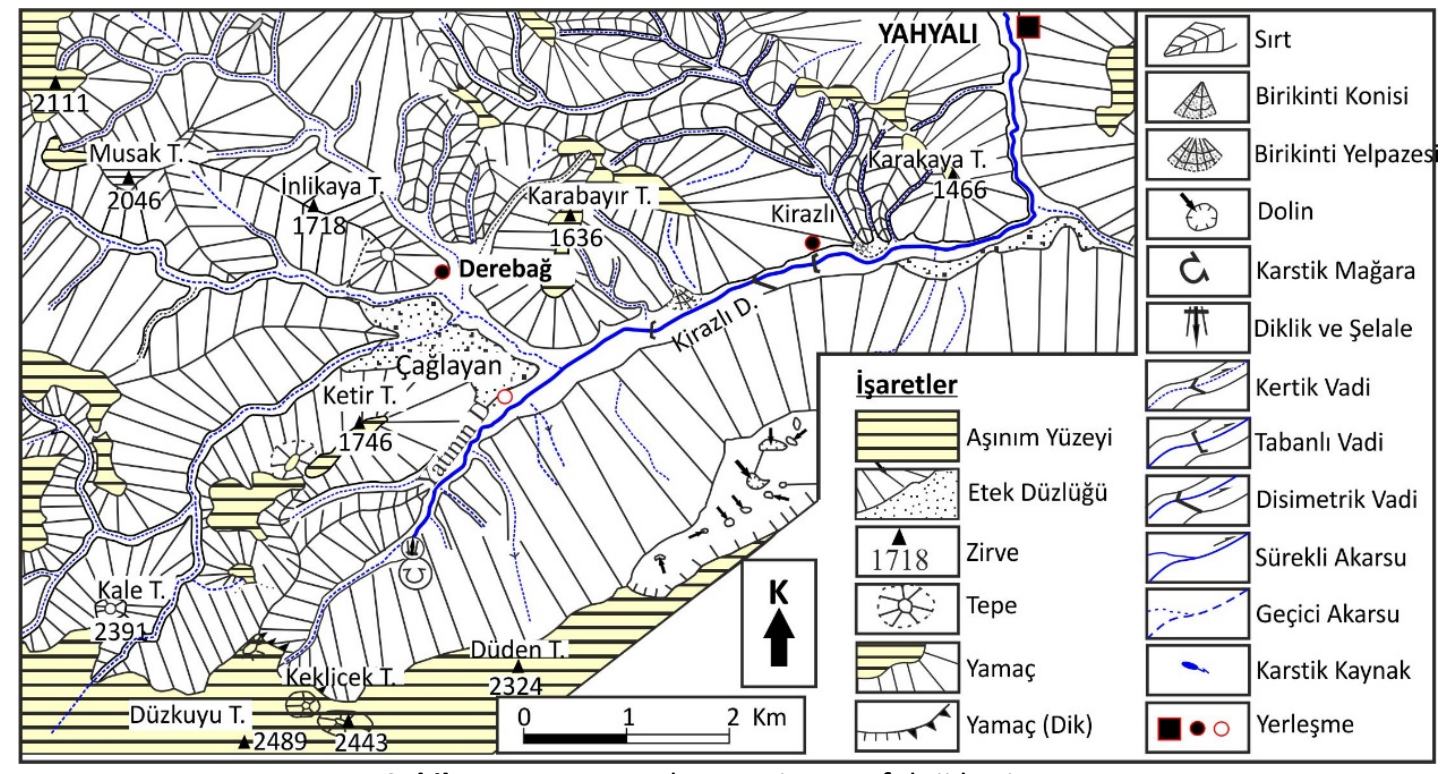

Şekil 5. Araştırma sahasının jeomorfoloji haritası.

Figure 5. Geomorphological map of the study area. 
Aladağlarda (Orta Toroslar) Kaynak Konumlu Bir Mağara: Derebağ Mağarası (Yahyalı-Kayseri)

Aladağların zirveler bölümü ile bu bölümün dışında kalan kesimleri arasında jeomorfolojik olarak belirgin bir farklılık vardır. Zirveler bölümü eski ve yeni yerşekillerinin çeşitliliği bakımından en zengin bölümü oluşturmaktadır. Zirveler dışında kalan sahalar daha sade görünüme sahiptir. Bu durum karasallaşma sürecinin başladığı Paleosen'den (Törk, 2008) başlayarak günümüze kadar devam eden tektonik hareketlerden kütlenin yüksek kesimlerinin daha fazla etkilendiğini göstermektedir. Neotektonik dönemle birlikte Aladağlardaki hızlı yükselim beraberinde hızlı aşınmaya ve karst taban seviyesinin derinleşmeye başlamasına yol açmıştır. Özellikle Pliyosen ve Kuvaterner'de hızlı yükselimin doğal bir sonucu olarak eski şekiller aynı hızla aşındırılmış hatta zirveler bölümündeki karst topografyası Pleistosen buzun dönemlerinde tamamen sıyrılmış, çok evreli yapıya sahip karstlaşmada yatay, sığ karst sistemleri yerini dikey yönde gelişen karstmağara sistemlerine bırakmıştır. (Törk vd., 2008). Gerçekten Aladağların zirveler bölümünde tespit edilen tahrip olmuş epikarstik şekiller Kuvaterner öncesinde etkili bir epijenik karstlaşma meydana geldiğine tanıklık etmektedir (Törk, 2008). Kuvaterner'in glasiyal dönemlerinde ise özellikle kütlenin buzulla örtülen bölümlerinde karstlaşmanın durduğu ve/veya yavaşladığı ancak interglasiyal dönemlerde yüzey ve derinlik karstının hızlandığı anlaşılmıştır (Törk, 2008). Günümüzde ise eskiye nazaran zayıflamış olsa da karstik ve flüviyal süreçlerin şekillenme üzerindeki etkisi devam etmektedir.

Çalışma sahası ve yakın çevresi Aladağ kütlesinin sınırlı bir kesimini temsil etmektedir. Şekil çeşitliliği bakımından kütlenin zirveler bölümüyle karşılaştırıldığında nispeten daha tekdüze bir topografyaya sahiptir. Bununla birlikte inceleme alanında değişik etmen ve süreçlerle oluşturulmuş şekiller bulunmaktadır. Bunlar arasında aşınım yüzeyleri, tek tepeler, vadiler, basık sırtlar, birikinti koni ve yelpazeleri, Derebağ Mağarası, $1850 \mathrm{~m}$ ve daha üst basamaklarda lapya ve dolin gibi yüzey karstlaşmasına özgü poligonal karstik şekiller gösterilebilir. Nitekim Düden Tepe (2324 m) ve Karacagüney mevkiinde çok sayıda sığ dolin bir araya gelerek tipik bir dolin topografyası meydana getirmiştir. Keklicek tepe $(2443 \mathrm{~m})$ kuzeydoğusundaki dolinler de benzer oluşumlara örnek oluşturmaktadır. Dolinlerin bir kısmının tabanında tarım yapılmaktadır.

Hidroğrafik Özellikler: Araştırma sahası hidrografik bakımdan Sultansazlığı Havzası içinde yer almaktadır. Havzanın Aladağlar'dan kaynağını alan en önemli akarsularından biri Yahyalı Çayı'dır. Bu akarsu kabaca güneye doğru akan Zamantı Irmağı'nın aksine kuzeydoğu istikametinde ilerleyerek Sultansazlığı Havzası'na drene olmaktadır. Yahyalı Çayı beslenme sahasını Kirazlı ve Yatının dere vasıtasıyla kütlenin yüksek kesimlerine uzatırken kestiği topografyada mağaranın hem sularını kapmış hem de eğimi ortalama 77 dereceyi bulan vadi yamacında askıda kalmasını sağlamıştır.

Sahada birçok karstik kaynak bulunmaktadır. Bunlardan biri de Derebağ (Gözpınarı) karstik kaynağıdır (Fotoğraf 2). Kaynağın debisi mevsimlik olarak değişmekle birlikte ortalama $0,5 \mathrm{~m}^{3} / \mathrm{sn}$ olarak ölçülmüştür (Özyurt, 1998). Mağara içine kadar yerleştirilmiş cebri borularla bu suyun bir kısmı alınarak içme suyu olarak değerlendirilmektedir. Sahada bundan başka bir kaç düşük debili karstik kaynak daha bulunmaktadır. Bu kaynakların büyük çoğunluğu Yahyalı Çayı ve kollarının topografyayı kestiği yamaçlar boyunca yüzeye çıkmaktadır.

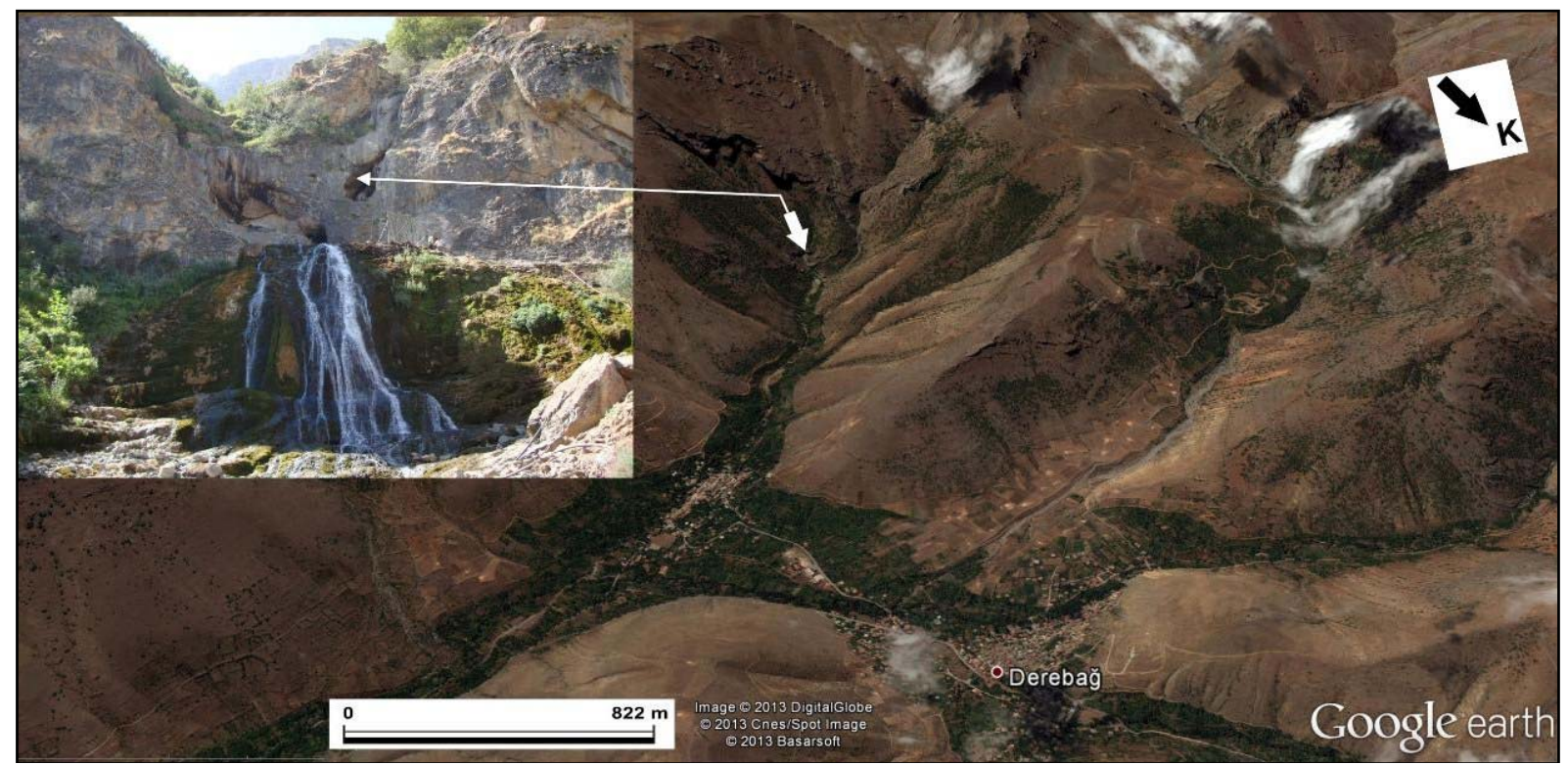

Fotoğraf 2. Derebağ Mağarası'ndan çıkan sular şelale yaptıktan sonra Yatının Dere'ye ulaşmaktadır.

Photograph 2: The waters coming out from the Derebağ Cave form the fall and then reach Yatının stream.

İklim Özellikleri: Aladağlar'ın kuzeyinde egemen olarak iç Anadolu karasal iklimine özgü koşullar görülmektedir. Ancak inceleme sahasındaki bitki örtüsünün genel karakteri ve yazın kaydedilen yağışların toplam miktarı göz önüne alındığında Akdeniz ikliminin tesirinde kaldığı görülür. Bazı çalışmalarda sahanın Akdeniz iklimi ile İç Anadolu karasal 
iklimi arasında yarı kurak step iklimine ait özelliklere sahip geçiş kuşağı içinde yer aldığı ifade edilmektedir (Erinç, 1993; Toroğlu ve Eser Ünaldı, 2008). Geçiş tipinde iklimin genel karakteri yazları sıcak ve kurak kışları soğuk ve yağışı olmasıdır. Buna göre iklim koşullarını daha somut belirlemek amacıyla Yahyalı meteoroloji istasyonuna ait verilerden yararlanılmıştır (MGM: 2005). Uzun yıllık meteorolojik verilere göre sahanın yıllık ortalama sıcaklığı $11.2^{\circ} \mathrm{C}$, yıllık ortalama toplam yağış tutarı ise $451.2 \mathrm{~mm}$ 'dir. En sıcak ay $22.2^{\circ} \mathrm{C}$ ortalamayla temmuz, en soğuk ay $1.6^{\circ} \mathrm{C}$ ortalamaya sahip şubat ayıdır. En yağışlı mevsim ilkbahar (176.8 mm), en kurak mevsim ise yaz (44.9 $\mathrm{mm}$ ) mevsimidir. Toplamda yaz yağışları tutarının 200 mm'den az oluşuna bakarak sahanın Akdeniz iklimi tesirinde olduğu söylenebilir. Thornthwaite yöntemine göre sahanın iklim tipi $C 1 B^{\prime} 1 s b^{\prime} 3$ harfleriyle ifade edilen 'yarı nemli-yarı kurak, orta sıcaklıkta, su fazlası kış mevsiminde ve orta derecede olan okyanus iklimine yakın iklim'dir. Buna göre; temmuz, ağustos ve eylül aylarında toprakta güçlü şekilde su noksanı vardır. Ayrıca bir yıl içindeki kurak günlerin sayısı 95.7 günü bulmaktadır (Kopar, 2009; Kopar, 2010).

Toprak Özellikleri: Sahada egemen olarak zonal toprak grubu içinde yer alan kahverengi orman toprakları ve kırmızımsı kahverengi Akdeniz toprakları yer almaktadır. Bu toprakların dışında sahada intrazonal topraklardan kuvarsit ve kuvarsit şistler üzerinde sığ kumlu topraklar, kireçlikumlu çökeller üzerinde sığ topraklar ve vadi tabanlarında alüvyal ve etek yüzeyleri boyunca kolüvyal topraklar görülmektedir. Gerek zonal ve gerekse azonal grup içinde yer alan topraklar iklim, yükseklik, anakaya, eğim ve erozyon gibi nedenler yüzünden genellikle iyi horizonlaşma göstermeyen sığ ve taşlılık oranı yüksek topraklardan oluşmakta, hatta toprak alanları içinde geniş çıplak kayalık kesimler bulunmaktadır.

Doğal Bitki Örtüsü: Araştırma sahasında doğal bitki örtüsü belli kesimlere sığınmış kuru orman bakiyeleri dışında tümüyle antropojen bozkırlardan meydana gelmektedir. Kuru ormanlar 1350 m -2400 m aralığında özellikle kuzeye dönük nispeten kuytu yamaçlarda yer almaktadır. Birlik düzeyinde olan bu ormanların asıl üyelerini tüylü meşe (Quercus pubescens) ve saçlı meşeler (Quercus cerris) oluşturmakta ve meşe birlikleri alt katında yer yer iştirakçi olarak ardıçlar (Juniperus excelsa. Juniperus oxycedrus), yabani armut (Pyrus olaeagrifolius), çakal eriği (Prunus spinosa), geyik dikeni (Cratiagus orientalis), yabani badem (Amygdalus orientalis), menengiç (Pistacia terebinthus), kuşburnu (Roza canina), yapışkan yapraklı laden (Cistus laurifolius), cehri (Rhamnus oleoides) ve karamuk (Berberis vulgaris) gibi türler görülmektedir (Eser Ünaldı ve Toroğlu, 2007). Antropojen bozkır alanında ise çoban yastığı (Acantholimon sp.) geven (Astragalus sp.) ve sığırkuyruğu (Verbascum sp.) gibi türler hâkimdir.

\section{DEREBAĞ MAĞARASI'NIN ÖZELLIKLERI}

\section{Oluşum ve Gelişim}

Derebağ Mağarası, Siyah Aladağ istifinde geniş alan kaplayan Üst Permiyen Mizzialı kireçtaşları (Ayhan vd., 1984) içindeki çatlakları izleyen yeraltı suyunun gerek hidrolik gerekse çözerek aşındırması ve genişletmesi sonucunda oluşmuş, görünürde iki galerili genç bir mağaradır.

Mağara, Pleistosen'de Yahyalı Çayı ve kollarının Sultansazlığı Havzası'nın denetlediği yerel taban seviyesine uyumla yatağını derinleştirmesi ve geriye aşınımla Keklicek tepeye $(2443 \mathrm{~m}$ ) doğru sokularak topografyayı kesmesiyle vadi tabanından yaklaşık 63 metre yukarıda askıda kalmıştır (Şekil 6).

Mağaranın oluşum ve gelişimi farklı hidrolojik kuşaklarda sürmüştür. Başlangıçta friatik (doygun) zonda şekillenme sürerken bilahare çatlakların genişlemesi ve özellikle yerel taban seviyesinin alçalmasına bağlı olarak mağara içindeki suyun yeryüzüne çıkışını sağlayan koşulların oluşmasıyla ana galeride vadoz (havalanma) koşullar egemen olmuştur. Ancak mağara içinde damlataşı şekillerinin her yerde görülememesi vadoz şartların güçlü beslenme dönemlerinde zaman zaman friatik koşullar lehine bozulduğunu ve damlataşı çökelimi şartlarının oluşamadığını göstermektedir Günümüzde ana galeride görünür şekilde ve diğer geçitlerde görünmez yeraltı deresi-dereleri şeklinde sürekli su akışı bulunmaktadır. Bu husustan hareketle mağaranın su tablası oynama zonu'nda (Nazik, 2008) gelişimini sürdürdüğü söylenebilir.

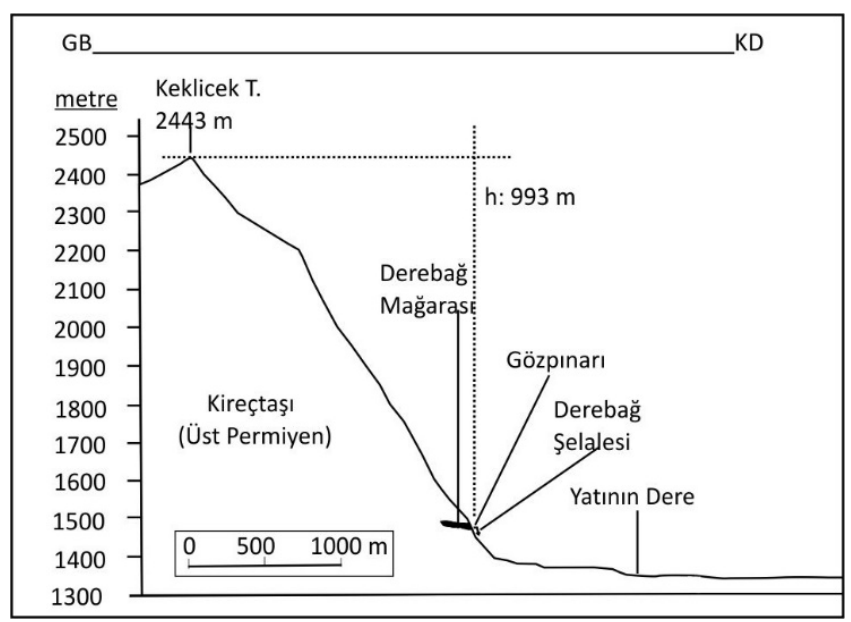

Şekil 6. Mağara Yatının Dere vadisinin tabanından yaklaşık 63 metre yukarıda askıda kalmıştır.

Figure 6. The cave stands above about 63 meters above the valley bottom of Yatının Brook.

Derebağ Mağarası, ana galeride ortaya çıkan suyun mağara içinde sürekli akışa sahip olması dolayısıyla aktif; fakat ana galeriye dik şekilde kenetlenen asimetrik elipsoidal şekilli geçit galerisinde belirli dönemlere su bulundurması bakımından yarı aktif bölümlü ve ağzından su çıkması nedeniyle kaynak konumlu bir mağaradır. 


\section{Derebağ Mağarası'nın Şekli}

Mağara " $T$ " şekilli olup biri ana galeri diğeri bir dirsekle ona bağlanan sifon şeklinde yarı aktif geçit galerisi olmak üzere iki galeriden oluşmaktadır (Şekil 7). Ayrıca geçidin altında ana galerinin suyunu bir yeraltı deresi şeklinde yeryüzüne ulaştıran başka yarık ve çatlak şekilli geçitler bulunmaktadır. Toplam uzunluğu 90 metreyi bulan mağaraya geçit galerisinden girilmekte ve geçidin bitiminde ana galeriye (salona) ulaşılmaktadır.

Mağaranın iki galeriden meydana gelmesinin nedeni; ana çatlak sistemi veya tabaka doğrultusuna bağlı ilksel gelişim yanında Sultansazlığı Havzası'nın derinleşmesine paralel olarak oluşan yeni kaide seviyesine göre gençleşen Yahyalı Çayı'nın sistemde ilk oluşan (ana galeri) bölümü kapmasıdır. Bu olay neticesinde çatlak boşluklarının daha da gelişmesi ve geçit özelliği kazanması mümkün olmuştur. Ayrıca süreç içinde yeni yeni yeraltı boşluklarının meydana gelmesi, geçit galerisi ve bazı çatlak boşluklarının hidrolojik açıdan yarı aktif konuma geçmesi ve ana galerideki suyun geçit galerisinin ortalama 2,5-3 metre altındaki yeni boşlukları kullanması da yerel kaide seviyesinin değişmesiyle ilgili olmalıdır.

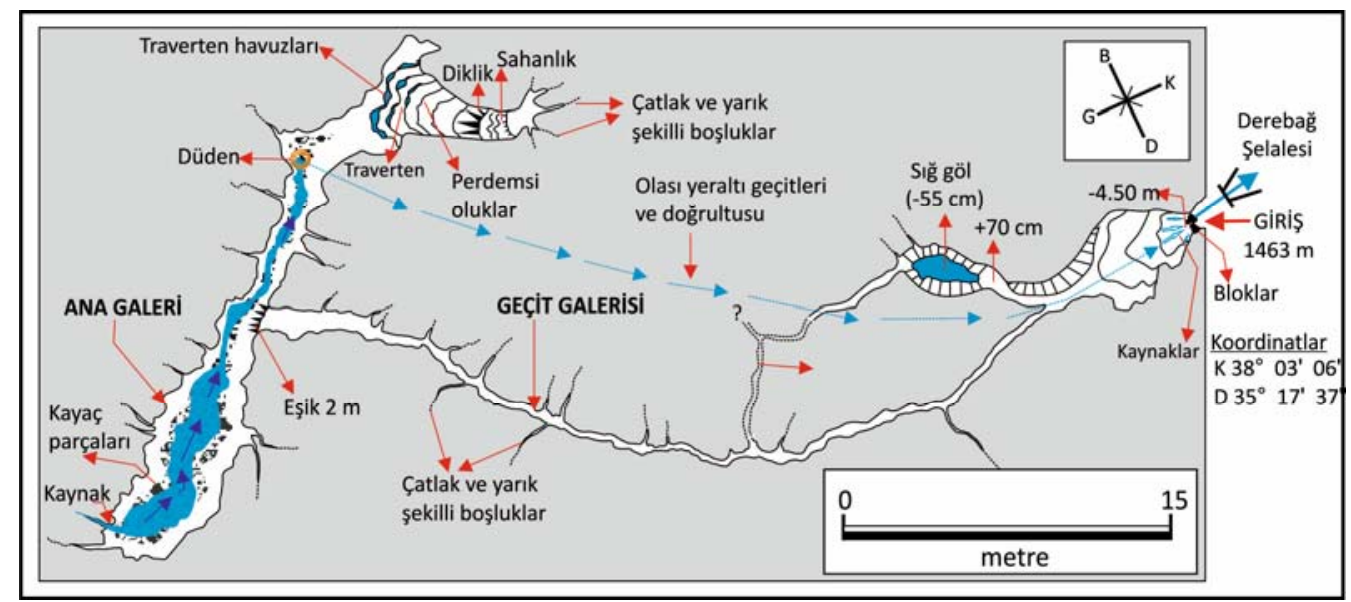

Şekil 7. Derebağ Mağarası'nın planı.

Figure 7. Plan of the Derebağ Cave.

Girişten itibaren ana hatlarıyla kuzey-güney doğrultusunda uzanan ve hafif bir yay çizdikten sonra ana galeriye bağlanan birinci galeri ana galerinin suyunu zaman zaman bir sifon şeklinde çalışarak yeryüzüne taşıdığı için geçit galerisi olarak isimlendirilmiştir (Şekil 8). Geçidin uzunluğu 57 metre, tavan yüksekliği ortalama 1,5 metre ile maksimum 3 metre, genişliği ise 1 metre ile maksimum 2 metre (ana galeri yakınında) arasında değişmektedir. Geçit galerisi bu değerle Derebağ Mağarası'nın en uzun ve içinden yürüyerek geçilebilen boşluklar bakımından en dar bölümünü temsil etmektedir. Galerinin girişinden itibaren ilk 5 metrelik bölüm dışında ana galeriye kadar olan bölümünde mağaraların ilk oluşum evresinde görülen ve dolayısıyla gençlik (başlangıç) dönemini karakterize eden asimetrik elipsoidal boşluklu (Nazik, 2005) enine profil hakimdir. Geçidin ortalarına doğru enine profil etkin çatlak yönünde gelişen damla çatlak boşluğuna (Nazik, 2005) benzer görünüm kazanmaktadır (Fotoğraf 3). Bu yapı, suyun çatlağın uzanış şekline uygun biçimde ilerlerken dönel hareketler yaptığını ve en çok yanal (lateral) şekilde çatlak düzlemini aşındırıp genişlettiğini göstermektedir.

Geçit galerisi başlangıçta herhangi bir kesinti olmaksızın ana galerinin suyunu mağara dışına taşırken sahanın tektonik hareketlerle yükselmesi ve ana galerinin tabanının derinleşmesiyle zaman içinde hidrolojik olarak yarı aktif bir duruma geçiş yapmıştır. Nitekim geçidin ana galeriye bağlandığı yerdeki ağzı, ana galerinin tabanından itibaren 2 metre yukarıda askıda kalmıştır. Bununla birlikte geçit, ana galerideki suların tahliyesini yapan yeraltı düdeninin tıkanması veya beslenmenin fazla olduğu zamanlarda su seviyesinin yükselmesiyle yetersiz kalması durumunda fazla suyun mağara dışına çıkmasını sağlayan bir sifon görevini üstlenmektedir. Galeri duvarında yer yer akıma dair ipuçları olabilecek ve bazı yerlerde açık seçik takip edilebilen film şeklinde tortu izlerinin bulunması, tabanda sediman birikiminin görülmemesi ve en önemlisi damlataşı şekillerinin bulunmaması ana galeriden gelen suyun yılın belli bir döneminde de olsa geçidi kullandığını göstermektedir. Zaten fotoğraf 5 'te de suyun gür bir şekilde geçitten dışarıya çıkışı net olarak görüntülenmiştir.

Geçit, ana galeriye bağlandığı eklemden başlayarak mağara ağzına doğru gittikçe alçalmaktır. Ayrıca geçidin ağız kesimi içeriye doğru ana çatlak doğrultusunda aşınarak kesilmiştir. Bu nedenle mağaraya girerken tedbirli olmak gerekmektedir.

Geçit galerisinin bitiminde ana galeri bulunmaktadır. Ana galeri kuzeybatı-güneydoğu doğrultusunda gelişmiş olup toplam 33 metre uzunluğa sahiptir. Enine profili geçit galerisinde olduğu gibi asimetrik elipsoidal şekillidir. Ancak ana galerideki bu profil genişlik ve yükseklik bakımından daha olgundur. Galerinin tavan yüksekliği maksimum 3.7 m 


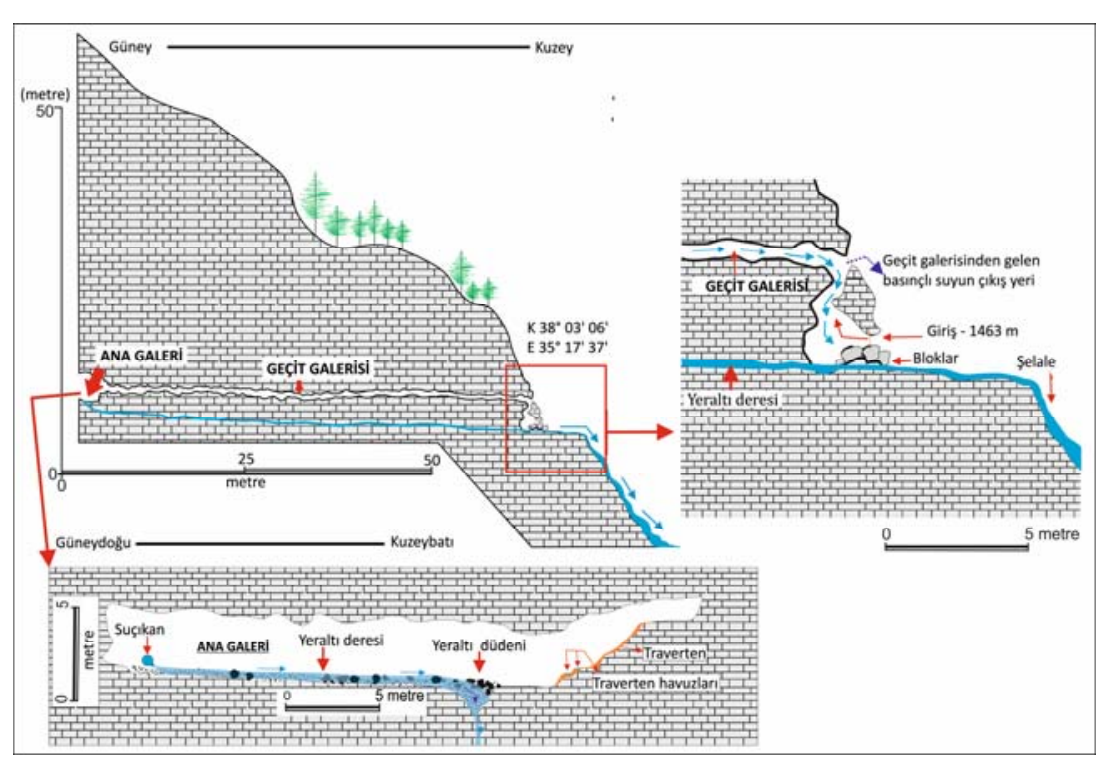

Şekil 8. Derebağ Mağarası'nın izdüşürülmüş boyuna kesiti.

Figure 8. Projective longitudinal cross section of the Derebağ Cave.

genişliği ise maksimum 4.7 metredir. Ölçüm değerleri dikkate alındığında ana galeri, Derebağ Mağarası'nın en erken oluşan dolayısıyla en yaşlı bölümünü temsil etmektedir.

Ana galerinin güneydoğu ucunda tabandan 85 santimetre yukarıdaki bir çatlak boşluğundan su çıkmaktadır. Bu su çıkış yerinden itibaren 19 metre uzunluğunda bir dere oluşturarak çatlak boşluklu bir düdenden ${ }^{1}$ yeraltına intikal etmekte ve geçit galerisiyle hemen hemen aynı uzunlukta yeraltı geçitleri veya yarık şekilli boşlukları kullanarak mağara dışına çıkmaktadır.

Ana galerinin tabanında yer yer tavandan ve duvarlardan koparılmış iri çakıl (200-2 mm) boyutundan blok (>200 mm) boyutuna değişen köşeli kayaç parçaları bulunmaktadır. İri kayaç parçaları genellikle kaynak tarafında yoğunlaşırken daha küçük olanları düden içinde ve çevresinde toplanmıştır. Bazı büyük kayaç parçalarının düştüğü ortamdan uzaklaştırılamaması büyük olasılıkla galeri tabanının yatay konumlu olması ve galeri içindeki suyun hızıyla ilişkili bir durumdur.

Ana galeriye yarık ve çatlaklarla çok sayıda bağlantı bulunmaktadır. Bu çatlak sistemi mağaralarda galerilerin uzanış doğrultusunu belirlemesi bakımından önem arz etmektedir (Kopar 2008). Nitekim kireçtaşından oluşan yereyde biri kuzeybatı-güneydoğu diğeri kabaca kuzeygüney istikametinde iki büyük galeri meydana gelmiştir. Bu galerilerle irtibatlı başka geçitlerin olduğunu ana galeriden bir düdenle yeraltına intikal ederek mağara ağzından çıkan sular göstermektedir. Ayrıca geçit galerisine bağlantılı olduğunu düşündüğümüz asılı konumda, 5 metrelik bölümüne ulaşılabilen başka bir paralel geçit daha bulunmakta ve içinde derinliği 50-55 santimetreyi bulan tekne şeklinde küçük bir sürekli göl bulunmaktadır. Göl muhtemelen sözü edilen çatlak ve yarık şekilli boşluklardan süzülen sularla beslenmektedir.

\footnotetext{
1 Düdenin ağzı kayaç parçalarıyla örtülü olduğu için ölçü alınamamıştır.
}

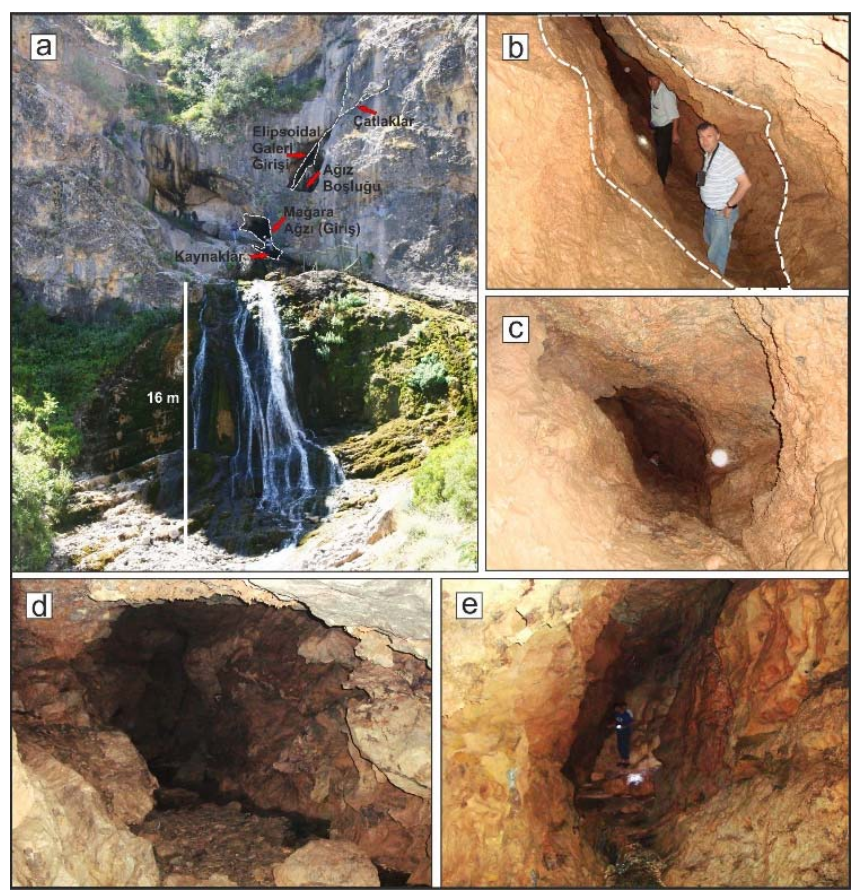

Fotoğraf 3. (a) Derebağ Mağarası'na geniş bir ağızdan girilmekte daha sonra asimetrik elipsoidal boşluklu bir galeriden geçilerek ana galeriye ulaşılmaktadır. Mağara ağzından çıkan sular Derebağ Şelalesi'ni meydana getirmektedir. (b-c) Geçit galerisindeki elipsoidal boşluklu yapı. Bu yapı henüz gençlik safhasında olan mağaralarda görülmektedir. (d) Ana galerinin kuzeybatısına doğru akan su bir düdenle yeraltına intikal etmektedir. (e) Ana galerinin güneydoğusunda traverten şekilleri ve havuzcuklar yer almaktadır.

Photograph 3. a) The entrance of the Derebağ Cave is through a wide mouth, which is followed by an ellipsoidal gallery that goes to the main gallery. The waters coming out from the mouth of the cave form Derebağ Fall. $b$-c) The ellipsoidal cavernous formation in the passage gallery. This formation is seen in young caves. d) The water falling northwestern the main gallery goes underground through a doline. e) There are travertines and ponds southeastern the main gallery. 
Aladağlarda (Orta Toroslar) Kaynak Konumlu Bir Mağara: Derebağ Mağarası (Yahyalı-Kayseri)

Derebağ Mağarası damlataşı şekilleri bakımından son derece fakirdir. Nitekim mağaranın ancak belirli bir kısmında yamaçtan süzülen sulardan kalsiyum bikarbonatın çökelmesi sonucunda traverten ve damlataşı havuzları gözlenmiştir (Fotoğraf 4). Bunun dışında tavandaki bazı küçük çaplı makarna sarkıtlar $(3-7 \mathrm{~cm})$ hariç dikkate değer başka damlataşı oluşumlarına rastlanmamıştır. Mağaranın şekil yönünden fakir olmasının kayaç özellikleriyle ilgili olmadığı mevcut damlataşı şekillerinden anlaşılmaktadır. $\mathrm{Bu}$ durumun olası nedeni, boşlukların yakın zamanda havalanma zonu koşullarına geçmesi ve zaman zaman boşluklar suyla dolduğu için friatik koşullarda suyun çözelti ile çökel materyaller arasındaki hassas dengeyi bozarak damlama ile çökel oluşumuna izin vermemesidir.

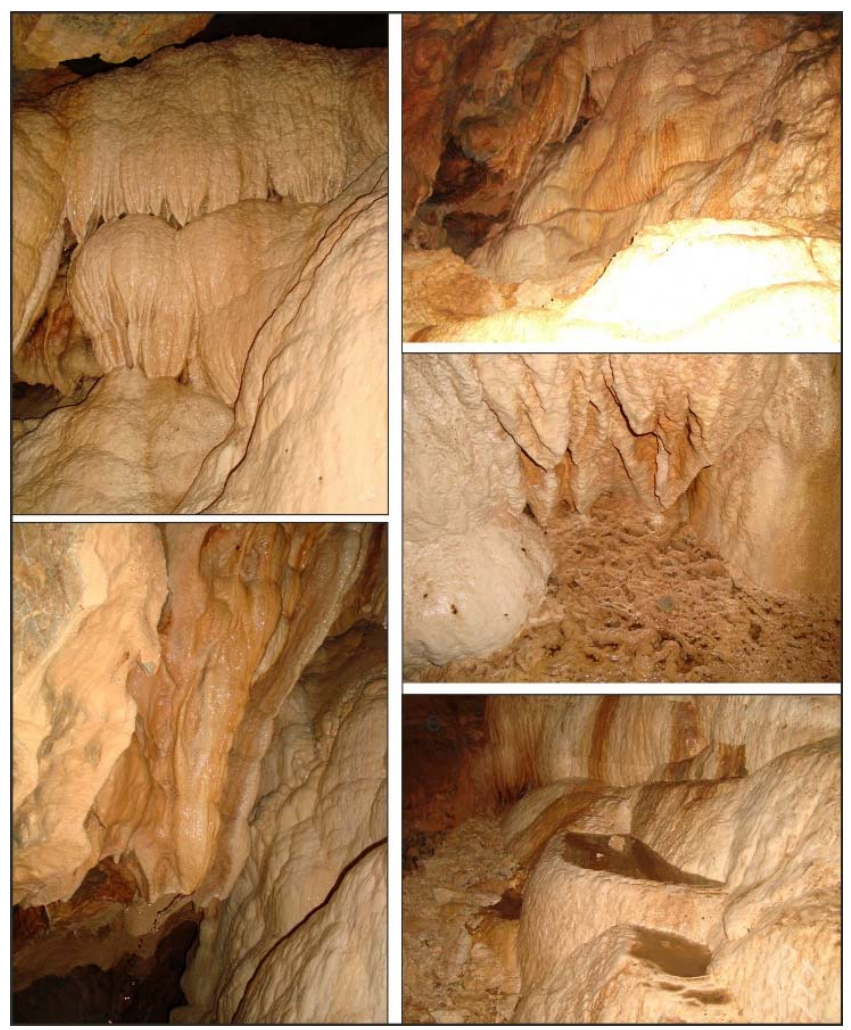

Fotoğraf 4. Derebağ Mağarası'ndaki ana galerinin güneydoğusunda görülen travertenler ve damlataşı havuzları.

Photograph 4. The travertine and dripstone ponds found southeastern the main gallery of the Derebağ cave.

Mağaranın en dikkat çeken şekli olan kirli sarı renkli traverten ve damlataşı havuzları ana galerideki düdenin kuzeydoğusunda yer almaktadır. Tavandaki çok sayıda çatlak boşluğundan süzülen sular bir sahanlığa (yaklaşık 8 $\mathrm{m}^{2}$ ) akıp oradan da eğimi 75 dereceyi geçen hafif dışbükey mağara duvarında yukarıdan aşağıya doğru yelpaze gibi açılan 6 metre boyundaki traverteni oluşturmuştur. Travertenin kalınlığı etekte 1 metreden fazladır. Travertende farklı çökelme dönemlerini temsil eden lamina ölçeğindeki büyüme tabakaları seçilebilmektedir.

Travertenin eteğindeki çıkıntılarda alt alta ve yan yana sıralanmış küçüklü büyüklü 6 adet damlataşı havuzu bulunmaktadır. Bu havuzlardan en büyüğünün kısa ekseni
36 santimetre, uzun ekseni ise 94 santimetredir. Ayrıca travertenin yüzeyinde aşınmayla oluşmuş birbirine paralel ve az keskin sırtlarla birbirinden ayrılan perdemsi oluklar görülmektedir. Olukların derinliği ile sırtların yüksekliği (maksimum 1,5-3 cm) yukarıdan aşağıya doğru artmaktadır.

Mağara tabanından daha yüksek bir konumda yer alan travertende laminalı tabakalanmanın varlığı ve bu tabakaların dike yakın eğimde oluşu çatlak boşluklarından gelen suyun mağara duvarından sızarak aktığını, akıntı saçakları üzerinde yer alan küçük ölçekli damlataşı havuzlarının varlığı ise çökelmenin duvara temaslı yavaş akan suyun akış yönüne dik duran ilksel çıkıntılarla karşılaştığını (Ayaz, 2002) ve bu seviyede hızın düşmesiyle damlataşı çökeliminin oluştuğunu göstermektedir.

Geçit galerisinin hemen altındaki ana galeriyle bağlantılı boşlukları izleyerek yeryüzüne çıkan ve şelale oluşturan karstik kaynaklar sürekli akışa sahiptir². Kaynakların yıl içindeki debisi mevsimsel olarak değişmektedir. Özellikle kar erimelerinin arttığı ilkbaharda kaynakların debisi yükselmekte, yaz mevsiminin sonuna doğru su miktarı iyice azalmaktadır. Kaynak suları kurak devrede geçidin altındaki boşluklardan geçerek 4 ağızdan yeryüzüne çıkmaktadır. Genelde ağustos ayı ortalarına doğru mağaradan yeryüzüne su çıkışı sadece tek ağızdan gerçekleşmektedir. Yan yana yer alan ağızlardan en büyüğü oval şekilli olup diğer çıkışların tam ortasındadır. Ağzın genişliği 1,5 metre, yüksekliği ise 24 santimetredir. Diğer ağızlardan birinin genişliği 73 santimetre, yüksekliği ise 32 santimetre, diğerinin genişliği 55 santimetre, yüksekliği ise 85 santimetredir. Hâlihazırda su çıkan dördüncü ağzın genişliği 46 santimetre yüksekliği ise 33 santimetredir. Illkbaharda debinin iyice artması neticesinde geçit galerisi de dâhil olmak üzere bağlantılı bütün galerilerden gür şekilde su çıkmaktadır (Fotoğraf 5).

Mağaranın yeryüzüne açılan küçüklü büyüklü bütün ağızlarından çıkan sular mağara önündeki sahanlıkta toplanarak Derebağ Şelalesi'ni oluşturmaktadır. Toplamda 6 metre uzunluğundaki düz bir sahanlığı geçen sular 7 metre eninde ve 16 metre yüksekliğindeki dik yamaç boyunca, bol debili akım dönemleri hariç, çoğunlukla yatakla temasını kesmeden yüzeyin girinti ve çıkıntılarına uyarak vadi tabanına doğru adeta bir gelin duvağı gibi açılarak düşmektedir. Şelale suyu önce Yatının Deresi'ne buradan da Kirazlı Deresi'ne karışarak Yahyalı Çayı'na drene olmaktadır.

\footnotetext{
2 28.08.2009 tarihli Sağlık Bakanlığı Kayseri il Halk Sağlığı Laboratuarı Müdürlüğü’nün 8379 protokol numaralı kaynak suyu analiz raporunda Derebağ (Gözpınarı) kaynak suyunun 17.02.2005 tarih ve 25730 sayılı resmi gazetede yayınlanan "insani tüketim amaçı sular hakkındaki yönetmelik" hükümlerine uygun nitelikte olduğu belirtilmektedir.
} 


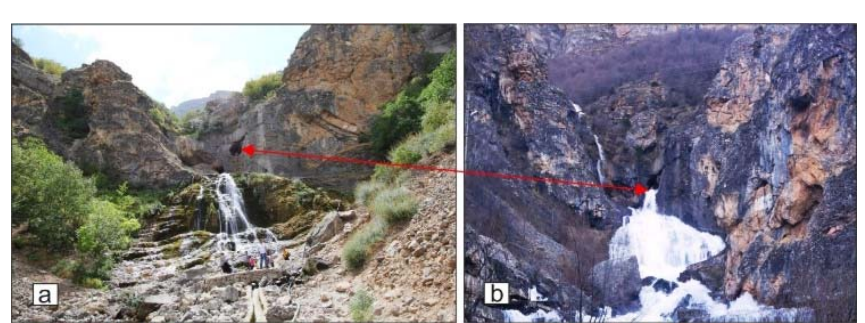

Fotoğraf 5. Yaz mevsimi (a) ve ilkbahar'da (b) mağaradan çıkan suyun konumu ve görünümü (Fotoğraf-b: Osman Sandık'tan alınmıştır).

Photograph 5. The location and appearance of the water that comes out of the cave in: a) summer and b) spring (Photograph-b were taken Osman Sandık).

\section{Mağara Havası}

Hava koşulları mağara ağzından başlayarak ana galeriye doğru değişmektedir. Ortam yarı aydınlıktan karanlığa hızlı bir geçiş göstermektedir. Bu doğrultuda sıcaklık ve nem koşulları da değişmektedir. Ağustos 2013 yılında yapılan ölçümlerde dışarıda sıcaklık değeri $25^{\circ} \mathrm{C}$ iken girişten birkaç metre ileride sıcaklık önce $20^{\circ} \mathrm{C}^{\prime}$ ye ana galeriyle bağlantı yerinde $15^{\circ} \mathrm{C}^{\prime}$ ye düşmektedir. Ana galeride $13^{\circ} \mathrm{C}$ civarında değişen sıcaklıklar ölçülmüştür. Buna göre mağara havası ılımandır. Mağarada su bulunması nedeniyle nisbi nem miktarı yüksektir. Nitekim nem miktarı yarı aktif sifonda \% 43-52 arasında iken içinde devamlı su bulunan ana galeride \% 76-79 civarında değişen değerler vermiştir. Bu nedenle ana galeri nemli, geçit galerisi ise kuru mağara olarak değerlendirilmiştir. Ayrıca mağara içinde uzun süre etüt yapılmasına rağmen çalışma ekibinden herhangi bir elemanda mağara havasından kaynaklanabilecek kulak çınlaması, uğultu, nefes darlığı, bulantı, kusma gibi olumsuzluklar gözlenmemiştir. Bununla birlikte mağaranın turizme açılmasına kesin olarak karar verilmesi durumunda insan sağlığını doğrudan etkileyecek gazların (oksijen, karbondioksit, karbonmonoksit, hidrojen sülfür ve diğ.) mutlaka belirlenmesi gerekir.

\section{Mağaranın Eko-Turizm Potansiyeli}

Mağaralar geleneksel turizmden farklı olarak tüm yıl boyunca sürdürülebilen aktivitelere sahne olabilen (Nazik, 2008) ve sahip oldukları özelliklerle bilimsel yararları yanında ziyaretçilerde büyük ilgi ve merak uyandıran mekânların başında gelmektedir. Derebağ Mağarası da hem kendi dinamikleri hem de ağzından çıkan suyun oluşturduğu şelale ile farklı ilgi gruplarına hitap edebilmekte ve her zaman yoğun ilgi çekmektedir. Yahyalı ilçe merkezine ve Aladağların zirveler bölümüne yakın olması, yörede turizm potansiyeli yüksek başka doğal mekânların (Zamantı Irmağı, glasyal şekiller, Kapuzbaşı Takım Şelaleleri, Yeşilköy Şelalesi, Kapuzbaşı (Divrik Dağı) Mağarası, Zindan-ı Köşk mağaraları gibi) bulunması mağara ve şelalenin çekim potansiyelini yükseltmektedir.
Damlataşı şekilleri bakımından zengin olmasa da yukarıda açıklandığı gibi kendine has özellikleri olan bu mağaranın turizme açılmasının yörenin kalkınmasına önemli katkılar sağlayacağı açıktır. Ancak mağaranın turizm amaçlı kullanılabilmesi için öncelikle şekil ve yapılara karşı hassas olunması ve korunması temel amaç olmalı, buna uyan bir yönetim planının oluşturulması gerekmektedir.

\section{SONUÇ ve ÖNERILER}

Derebağ Mağarası yüksek Aladağ kütlesindeki çok sayıda karstik mağaralardan sadece biridir. Ancak onu türdeşlerinden (fosil, düden, geçit, iki yönlü mağaralar) farklı yapan olgular, aktif ve yarı aktif konumlu bölümlere sahip olan genç bir mağara olması ve ağzından çıkan suyun 16 metre yükseklikten düşerek şelale oluşturmasıdır. Böylece mağaraya gelen ziyaretçiler hem mağarayı hem de mağaraya görsel olarak apayrı bir güzellik katan şelaleyi görme imkânı bulmaktadır.

Derebağ Mağarası gibi kaynak konumlu mağaraların çoğu su tablası oynama zonunda askıda kalmış durumdadır. Bu görünümdeki mağaraların vadi tabanından yukarıda olması ve giriş yerine ulaşmak için tırmanılması pek çok ziyaretçiye ilginç gelmekte ve onları heyecanlandırmaktadır.

Derebağ Mağarası'nın en zayıf tarafı damlataşı şekilleri bakımından fakir olmasıdır. Bununla birlikte sahip olduğu jeolojik, jeomorfolojik, hidrolojik ve klimatik özellikleri bilimsel açıdan mağaranın önemini artırmaktadır. Bu özellikler arasında aydınlık bir zondan aniden karanlık zonlara geçiş yapılan asimetrik elipsoidal boşluklu galeri ve bu galerinin sifon özelliğinde olması, ana galeride gür bir kaynağın ortaya çıkması, aynı suyun yeraltı deresi oluşturarak birkaç metre ötede çatlak şekilli bir düdenden tekrar yeraltına intikal etmesi ve kulak kabartıldığında sesi derinden duyulabilen yeraltı derelerini oluşturması, mağaranın kendine özgü iklimsel karakteri ve nihayet damlataşı şekillerini temsil eden birkaç şeklin (traverten yapıları ve havuzcuklar) bulunması gibi özellikler gösterilebilir.

Karstik mağaraların oldukça yüksek turizm değeri vardır. $\mathrm{Bu}$ sebeple Derebağ mağarası ve onunla bütünleşmiş estetik ve görsel değeri bulunan şelale gibi doğal yapıların insan yararına olacak şekilde değerlendirilmesi yöre ekonomisine önemli katkılar sağlayacaktır. Ancak yukarıda da ifade edildiği gibi doğal oluşumların turizm yararına kullanılması belli bir program dâhilinde, koruma-kullanma ilkeleri göz ardı edilmeden yapılmalıdır.

\section{KATKI BELIRTME}

Mağara etütlerine destek olan Yahyalı Belediye Başkanı Sayın Mehmet Araç'a, belediye personellerinden Sayın Osman Sandık, Ahmet Köylü ve İbrahim Toroğlu'na ayrı ayrı çok teşekkür ederiz. 


\section{KAYNAKLAR}

Ayaz, M. E. (2002). Travertenlerde Gözlenen Morfolojik Yapılar ve Tabiat Varlığı Olarak Önemleri, Cumhuriyet Üniversitesi Mühendislik Fakültesi Dergisi, Seri AYerbilimleri, 19/2: 123-134.

Ayhan, A., Lengeranlı, Y., Çeltek, N. ve Aksoy, E. (1984). Aladağlar (Batı Zamantı) Yöresi (Yahyalı-Çamardı) Jeolojisi ve Kurşun-Çinko Etütleri, MTA, Maden Etüd Dairesi, Rap. No: 7501 (1483), Ankara, 1-108.

Blumenthal, M. M. (1941). Niğde ve Adana Vilayetleri Dâhilindeki Torosların Jeolojisine Umumi Bir Bakış, Maden Tetkik ve Arama Genel Müdürlügü Yayını, Seri B, No: 6, Ankara.

Blumenthal, M. M. (1952). Toroslarda Yüksek Aladağ Silsilesinin Coğrafyası, Stratigrafisi ve Tektoniği Hakkında Yeni Etütler, Maden Tetkik ve Arama Genel Müdürlüğü Yayını, Seri: D, No: 6, Ankara.

Çelik, Ö. F. (1997). Aladağların Yapısal Özellikleri, Bölgesel Jeolojik Evrim ile ilişskileri, Çukurova Üniversitesi, Fen Bilimleri Enstitüsü, jeoloji Müh. Anabilim Dalı, Yüksek Lisans Tezi, Adana, 1-114.

Erinç, S. (1993). "Türkiye Fiziki Coğrafyasının Ana Çizgileri", İstanbul Üniversitesi Deniz Bilimleri ve Coğrafya Enstitüsü Bülteni 10: 1-8.

Eser Ünaldı, Ü. ve Toroğlu, E. (2007). Aladağlar'da Bitki Formasyonları ve Dağılışları, Gazi Üniversitesi Gazi Eğitim Fakültesi Dergisi 27/2: 227-240.

Kopar, i. (2008). "Elmalı Mağarası (İspir-Erzurum)”, Fırat Üniversitesi Sosyal Bilimler Dergisi 18/2: 71-90.

Kopar, i. (2009), “Aladağlar'da [Orta Toroslar (YahyalıKayseri)] İki Fosil Mağara: Zindan-ı Köşk-1 ve Zindan-ı Köşk-2", Türk Coğrafya Dergisi 53: 69-83.

Kopar, i. (2010). “Aladağların (Orta Toroslar) Fosil Mağara Potansiyelinden Yeni Bir Kayıt: Kapuzbaşı Mağarası (Divrik Dağı)”, Türk Coğrafya Dergisi 54: 31-42.

Nazik, L. (1989). "Mağara Morfolojisinin Belirlediği JeolojikJeomorfolojik ve Ekolojik Özellikler", Jeomorfoloji Dergisi 17: 53-62.

Nazik, L. (2005). “Mağara Nedir Nasıl Oluşur?” Ulusal Mağara Günleri Sempozyumu 24-26 Haziran-Bildiriler Kitabı: Konya. 1-18.

Nazik, L. (2008). Mağaraların Araştırılma, Koruma ve Kullanım ilkeleri, Ankara: MTA Genel Müdürlüğü, Yerbilimleri ve Kültür Serisi-2.

Nazik, L., Törk, K., Tuncer, K., Özel, E., İnan, H. ve Savaş, F. (2005). "Türkiye Mağaraları", Ulusal Mağara Günleri Sempozyumu 24-26 Haziran-Bildiriler Kitabı: Konya. 31-46.

Özgül, N. (1976). "Torosların Bazı Temel Jeoloji Özellikleri”, Türkiye Jeoloji Bülteni 19: 65-78.

Özyurt, N. N. (1998). Aladağlar Karst Akiferi (Doğu Toroslar) Boşalımlarında Kloroflorokarbon Esaslı Yeraltısuyu Geçiş Zamanının Belirlenmesi, Hacettepe Üniv., Fen Bilimleri Enstitüsü, Yüksek Müh. Tezi (Yayımlanmamış), Ankara, 1-108.
Sür, A. (1994). "Karstik Yerşekilleri ve Türkiye'den Örnekler", Ankara Üniversitesi Türkiye Coğrafyası Araştırma ve Uygulama Merkezi Dergisi 3: 1-28.

T.C. Orman ve Su İşleri Bakanlığı Meteoroloji Genel Müdürlüğü (MGM) (2005). Yahyalı'nın Meteorolojik Verileri, Ankara:, Veri Kontrol ve İstatistik Şube Müdürlüğü.

Tekeli, O. (1980a). "Toroslarda Aladağların Yapısal Evrimi” Türkiye Jeoloji Kurumu Bülteni 23 (1): 11-14.

Tekeli, O. (1980b). "Aladağ Ofiyolit Dizisindeki Diyabaz Dayklarının Kökeni". Türkiye Jeoloji Kurumu Bülteni 23: 15-20.

Tekeli, O., Aksay, A., Evren Ertan, İ., Işık, A. ve Ürgün, B. M. (1981). Toros Ofiyolit Projeleri Aladağ Projesi, MTA Raporu, No: 6976, Ankara, 1-125.

Tekeli, O., Aksay, A., Ürgün, M. B. ve Işık, A. (1984). "Geology of the Aladag Mountains", Symposium on the Geology of the Taurus Belt, Abstracts, General Directorate of Mineral Research \& Exploration, Ankara.

Toroğlu, E. ve Eser Ünaldı, Ü. (2008). “Aladağlar'da (Toros dağları) Bitki örtüsünün Ekolojik Şartları", Fırat Üniversitesi Sosyal Bilimler Dergisi, 18/2: 23-49.

Törk, K. A. (2008). Aladağlar'da (Niğde-Kayseri-Adana) Buzullaşma Evrelerinin Karstlaşma Üzerindeki Etkileri, Hacettepe Üniversitesi, Jeoloji (Hidrojeoloji) Anabilim Dalı, Doktora Tezi (Yayımlanmamış), Ankara, 1-140.

Törk, K. A., Nazik, L., Bayarı, C. S., Klimchouk, A., Özyurt, N. N. ve Özel, E. (2008). Aladağlar (Kayseri, Niğde, Adana) Bölgesinin Karst Evrim Süreçleri, Türkiye Mimarlar Mühendisler Odası Birliği (TMMOB)- Jeoloji Mühendisleri Odası (JMO) 61. Jeoloji Kurultayı 24-28 Mart 2008-Bildiri Özleri, Ankara.

\section{Internet Kaynakları:}

TMMOB-JMO (Türkiye Mimarlar Mühendisler Odası BirliğiJeoloji Mühendisleri Odası) (2013)

<http://www.jmo.org.tr/etkinlikler/kurultay/etkinlik_bildiri leri_detay.php?etkinlikkod=33\&bilkod=54>. Son Erişim Tarihi: 14.04.2013.

GOOGLE <http://www.google.com.tr/intl/tr/earth> Son Görüntüleme Tarihi: 10.05.2013. 
